\title{
THE MEANING OF GESTURE IN SOCIAL CULTURAL CONTEXT
}

\author{
Najamuddin \\ TadrisBahasaInggrisFTK UIN Mataram \\ najamuddin@uinmataram.ac.id
}

\begin{abstract}
This articlces intents to describe the meaning of gestures in sosial cultural context, especially for students in language learning and generally for language user which have different cultural background and to encourage an appreciation of cultural diversity and the process of intercultural communication.Students and people still find difficulties to learn, to understand the gestures and leaves them confused about what the meaning of gestures apply in context of situation and culture. This confusion is due to countless rules governing proper of gestures.Based on the brief explanation above, speakers of languages in certain cultures that use "gestures" can change the meaning or the meaning conveyed. Thus, the problem is like what gesture used by speakers of the language so that what is delivered is not responded well, of course based on different cultural backgrounds. Gestures serve different purposes in language. Function gestures make symbol of language has meaningful. Content of gestures are the symbols that communicate meaning in contexts. Clearly, people must know kinds of gestures to understand what they act.
\end{abstract}

Keywords: gestures, sosial cultural context, meaning

\begin{abstract}
Abstrak: Articlces ini bermaksud untuk menggambarkan makna gesture dalam konteks sosial budaya, terutama bagi siswa dalam pembelajaran bahasa dan umumnya untuk pengguna bahasa yang memiliki latar belakang budaya yang berbeda dan untuk mendorong rasa mengapresiasi keanekaragaman budaya dan proses komunikasi antar budaya. Siswa dan kebanyakan orang masih menemukan kesulitan untuk belajar, memahami makna gerakan dan membuat mereka bingung tentang apa arti gerakan dalam konteks situasi dan budaya. Kebingungan ini disebabkan oleh sejumlah aturan bahasa yang mengatur makna gerakan tersebut. Berdasarkan penjelasan singkat di atas, penutur bahasa dalam budaya tertentu yang menggunakan "gesture" dapat mengubah makna yang disampaikan. Dengan demikian, masalahnya seperti apa gesture yang digunakan oleh penutur bahasa sehingga apa yang disampaikan tidak dipahami dengan baik, tentu saja semuanya itu disebabkan atas dasar latar belakang budaya yang berbeda. Gesture menyampaikan berbagai tujuan dalam bahasa. Fungsi gerakan membuat lambang bahasa yang memiliki makna. Nilai dari gesture tersebut adalah simbol yang mengkomunikasikan makna dalam konteks. Jelas, orang harus memahami jenis gerakan tersebut agar dapat dipahami secara baik..
\end{abstract}

Kata-kata kunci: gesture, kontekssosialbudaya, makna 


\section{A. Introduction}

Language is a medium of communication between peoples. Interaction using language can be in the form of requests, offers, notifications, orders and prohibitions. In communication referred to language users are very bound by the rules of language based on the context and situation of the user. SutjiatiBaratha in Mbetesays that language is a social phenomenon, a product of human life in society ${ }^{1}$. The languagesystem is not a stand-alone, but is part of the social process, because language is part of culture. Language consists a set of choices, namely the meaning of language generated by the language itself.

Language has arbitrary nature. That is, a word will have no meaning if there is no agreement from the users. For example, the signal "nod your head" can be understood by Indonesian people which means "agree". However, for Indians this gesture means "disagree". This sometimes makes us misunderstand in a particular language. According to Oxford Advanced Learner's Dictionary means that language is a system of symbols that people use to give expression to thoughts and feelings. Language in a broad sense as a means of connecting which is not only expressed in words but also in gestures.

Language and socio-culture cannot be separated because the function of language is a medium of communication used by every human being in establishing social interactions. In the order of the life human beings definitely need in interacting with each other, therefore language has an important role in maintaining social relations, by giving a meaning of expressions related to social and individual attitudes, estimates, judgments, and others can be understood by people who have different cultures.

It is also said that language is part of culture. Language and culture are very important parts because they reflect the culture itself. Language and culture cannot be separated, so that in observing a language, a description of the culture of the owner of the language will be obtained, in addition to establishing social relations.

In certain cultures, especially communities that exist in these environments can be said to be a language society or "language society". This diversity is important to understand so that language users who have different cultural backgrounds can understand it so that good interaction can be established.

The cultural context is closely related in understanding among each-others, in this case every region or broader country has different way in expressing the thoughts or intentions to be conveyed either verbally, written or gestures. The cultural context has an important role in interpreting messages or information conveyed by local speakers who have special meaning in language habits.

1 SutjiatiBaratha,"Struktur dan Peran Semantis Verbal Ajaran Bahasa Bali" (Jakarta: Gunung Mulia, 2000), hlm. 286-288 
From this description, the author is very interested in discussing and expressing some parts of the way to speak of a particular society that has a different socio-cultural background. In addition, it is hope that it will be useful for language learning as well as researchers to explore and study more deeply about language ways, especially signals in certain communities. The discussion about this is always associated with symbols, messages that are not in the form of words, but in the form of gestures of body signals. The signals have wide meaning.

The goal that the author intends to describe here is the social interactive experience between different cultures that specifically uses "gestures" in expressing and giving meaning conveyed by speakers of that language. Analysis meaning is an effort to trace and understand the content of behind the form of expression as the actualization of functions which carried out in the socio-cultural reality. To study and understand signs, symbols or gestures used semiotic theory proposed by Ferdinand De Sassure. The application of this theory is refers to the object of study which related to the language.

\section{B. Theoretical Review}

Nonverbal Communication such "Gesture" in the context of socio-culture that need to be studied, because we always communicate, and not enough just to send verbal messages but also we cannot avoid sign language either through hand movements or facial appearance.

To understand the meaning of "gestures" in a cultural context, "gestures" are expressions through body that have special meanings (Levine, 1982: 44) and those used by speakers are examined through analysis of meaning. This meaning is relates with symbols, signs, and of language signs ${ }^{2}$.

Furthermore, in this study that human feelings were expressed through verbal, paralinguistic, and through nonverbal included with cues, limbs, facial expressions. In addition, speaking andwriting, the behavior create of meaning in other forms. And also Levine said that nonverbal language is an explanation of language as a medium communication, these can be in the form of vocabulary words (semantics) or in the form of cues. In other words, this nonverbal means is a message in the element of the communication process that is manifested in the form of a symbol or gesture.

The meaning in language which is expressed verbally, in writing and in the form of desire is part of the symbol which still requires a process of meaning. In this case (Kladen and Angela) explain that values or meanings are usually regarded as something related to culture or more specifically with the symbolic world in culture. ${ }^{3}$

Regarding the context are all situations and things that are outside the text and affect the use of language, such as participants in language, situations where the text

2 Levine.Beyond Languange Intercultural Communication for English as Second Languange. (USA: Printed In Printed Hall. Inc. Englewood Clifs:1982) hal.44

3 Kladen N.P. Seni Memahami Sebagai Metode Humanitor. (Jakarta: 1999) hal. 17 
is produced, the intended function and its parts. ${ }^{4}$ The study of thislanguage, includes context, because language is always in context, and there is no act of communication without participants, interactions, situations, and so on. ${ }^{5}$ Contextual meaning in this case "gesture" has an important role for users of language both from the sociocultural because the user of the language highly appreciates and applies it in daily life such as in the work environment, household, school and others.

\section{R esearch Method}

Provide an overview of the language context used in cross-cultural, so that it can add to the treasure of linguistic facts, especially Motion "gestures" in a social context. In addition, it is hoped that it will be beneficial for language learning and researchers to dig deeper into the basic ways, especially "gestures" in certain societies.Besides that, it can add insight to the community in understanding nonverbal communication that is used by people who have different cultures so that one can understand each other.

Analysis meaning is an effort to trace and understand the content of behind the form of expression as the actualization of functions which carried out in the sociocultural reality. To study and understand signs, symbols or gestures used semiotic theory proposed by Ferdinand De Sassure. The application of this theory is refers to the object of study which related to the language.

De Saussure's theory is related to general linguistic theory. This theory is related to the meaning of the sign that contains the interpretation or conception of the supporters. To understand the meaning of "gestures" is neededa process of understanding of hermeneutic, namely the process of interpretation related to sign language. According to Ricouer, hermeutic is a symptom of discipline that works by using interpretations and this is an activity to distinguish hidden meanings. ${ }^{6}$

\section{Result and Discussion.}

\section{Result}

Some forms of gesture "Gestures" that the writer shows can be used as a reference for language learning and research in the future. The forms of "Gestures" are as follows:
a. "Eye Contact".
b. "Strongly Handshaking".
c. The index finger and thumb are made into a circular "Finger Circle".

4 Alex Sobur. Analisis Teks Media.(Jakarta: Remaja Rosdakarya,2001) hal. 56

5 Eriyanto. Analisis Wacana: Pengantar Teks Analisis Media. (Yogyakarta: LKIS, 2001) hal.9

6 Sumaryono. Hemenetika Sebuah Metode Filsafat. (Yogyakarta: Kamisius, 1987) hal. 158 
d. "Pointed Finger on Head".

e. Facial Expression.

f. "Smile".

g. "Tumble Finger".

h. "Giving something with Left Hand".

i. "Rise Hands".

j. "Moving Head to Vertical position".

k. "Kissing".

1. "Looking a Time".

m. "Middle Finger".

n. "Eye Staring".

o. "Wrinkle the Head".

p. "Body Style".

q. "Meet Both Eye Brows"

r. "Wrinkle the Head".

s. "Body Style" Body Attitude.

t. "Fake Smiles"

u. "Waving Hands"

v. "Patting the Head"

w. 'Put all fingers together'

x. "Cross Finger".

y. "Rubbing the Chin"

z. "Calling by swinging the index finger"

aa. "Finger Biting"

bb. "Leaving Food at the Invitation to Eat"

\section{Discussion}

a. "Eye Contact".

"Gesture" is most often used by "western culture". Sometimes people with different cultural backgrounds feel "awkward" to use it. For example, Americans, blinking in one eye is a common expression in "greetings" even though previously they did not know each other or in other words made the atmosphere become "familiar". But on the contrary in other cultural contexts such interactions can be interpreted with different meaningslike something unusual because maybe they rarely use 
"contact eyes" in greeting someone especially didn't know each other. How to greet someone who is used directly. For speakers of other languages, "contact eyes" does not mean "greeting", it may be interpreted as saying "there is something wrong with me" or "something is wrong"

b. "Strongly Handshaking".

"Strongly Handshaking" is a "western" habit in expressing "intimacy", even though the first time meeting other people is especially in social interaction. However, for Indonesians "shaking hands" is only done "normal" by clenching and moving once without repeated many times and holding tightly. For Indonesians to shake hands tightly and move many times is very rarely used because the habit of handshaking is carried out moved only two to three times and not repeatedly. There are also other ways to use both hands by tapping together. This method is a little strange toward us because tapping both hands together is only done when in a game event or a symbol in informal greeting that is usually done by young people who meet their peers.

\section{c. "Finger Circle".}

"Finger Circle" describes an expression used by "western" which means "agree" or "OK". But in Indonesia this means different meanings when "finger circle" is used only to show some numbers ". Whereas in Brazil this "gesture" has the same meaning that is "impolite"." Finger Circle" can also be interpreted in certain cultures as an offer or transaction in deciding the value agreed upon by the seller and the buyer.

\section{d. "Pointed Finger on Head".}

Almost everyone who comes from any country using "gesture" shows the expression of someone who is "thinking", "reminding something that forgets" or more revealing an emotional expression. But those who interpret it as an expression "alert or careful to make a decision". Or just a style to show someone that something (meeting) can be decided.

\section{e. "Facial Expression".}

"Gesture" is often expressed in almost every country. "Facial Expression" is more likely to follow the content of the conversation such as feeling surprised, happy, awe, surprised, sad and not only expressed in words but can be shown with a face or facial expression. This can show fear in a terrible atmosphere. This expression is most often shown to children when he is playing or a kind of warning not to do things that his parents don't want it.

\section{f. "Smile"}

Almost everyone who comes from anywhere, "Smile" is an expression that is addressed to someone when they feel "happy" or "unhappy". Sometimes when "gesture" is expressed when encountering people we haven't known before, it might mean "greeting" or otherwise "strange" because they don't know each other.Smile is 
a feeling expression that is shown through lip folds which has a motion effect on the face and around the eyes. This gives a distinctive or special impression for opponents of interaction.

g. "Tumble Finger".

"Tumble Finger" especially for Indonesians is an expression of recognition "great", "good" or "agree". But if "Tumble Finger" is turned downward, it will mean "bad" or "not good" for westerners like England, Australia.The fingers have a very special meaning for certain community habits such as scratching, holding, writing, giving orders, placing rings and others included in the context of communication.

h. "Giving something with Left Hand".

This kind of "gesture" is almost in some places in Indonesia which has the meaning, "impolite". This is because the "left hand" is the hand that is used to clean the "remnants of dirt". However, for Americans, this kind of "gesture" is only natural and does not affect emotional attitudes.Gesture is very familiar to everyone but the position in showing or giving something to someone must be understood in terms of the socio-cultural side to avoid misunderstandings. Because the habits we do will be interpreted differently from certain people who can cause anger, dislike. Therefore it is very important in understanding the function of this gesture.

i. "Rise Hands".

The "Rise Hand" gesture lifts the palm upward like an Australian, American or other European country, "gesture" means "want to express an opinion" or "want to present yourself". But in Indonesia "Rise hand" means the phrase "goodbye". Same as above that showing or giving something to someone must be understood in terms of the socio-cultural side to avoid misunderstandings. Because the habits we do will be interpreted differently from certain people who can cause anger, dislike.

j. "Moving Head to vertical position".

Signs of "Head Movement" are at least two general movements, namely "up and down" (nodding) to express agreement and horizontal movements to the left and right (we call shaking your head) to express "disagree", "astonishment", and change ideas or ideas during a conversation. Almost every country "Gesture Moving Head" has meaningthe same, except Indians that the movement "nods up and down" states "disagree" while "shaking your head" means "agree".

k. "Kissing".

"Kissing" Kiss is a "gesture" to express emotional through mouth or nose contact which shows signs of "love" or "affection" both aimed at parents, children and married couples.In western culture this kind of gesture is considered normal even though it does not have an official "legal" relation for those who are married. 
But in eastern culture, there is a boundary that is insulated because of religious and socio-cultural factors. Kissing is only for legitimate couples, parents and children.

1. "Looking a Time".

In a good conversation in a discussion, meeting or joking with friends, sometimes hand movements to "see time" are often done. This "gesture" can indicate "interruption" of an ongoing conversation. This might indicate that the person is "in a hurry to go" or "insinuate someone who is late in coming". Sometimes it makes people uncomfortable or offended by this attitude, because sometimes there is something important to talk but the conversation is interrupted so the information to be presented is incomplete. This kind of part make some persons misunderstanding, on the other hand the person sees time due to promises that must be kept but on the other hand makes people offended.

m. "Middle Finger" brandishing the middle finger.

"Middle Finger" brandishing the Middle Finger is a gesture that is very "impolite" used for western people "western" because it means "cursing". But for some people this kind of gesture might be insignificant.According to the information that writer get, in other parts of the world "Middle Finger" is something that shows a part of a symbol to mentions family member, for example; thumbs are shown to Mom, index finger to Father, middle finger to older brother, ring finger to sister and little finger to younger sister. So it is very important to understand because not all countries interpret this gesture as swear but can also mean other symbols.

\section{n. "Eye Staring".}

For some people, "glaring at the eyes/eyes staring" during the course of a conversation can mean "paying close attention" but in other situations these signals can have other indications namely "dislike" or "angry" and can also cause offense for those invited to talk.Eye gaze has a wide meaning depending on how the situation is faced. Some people say that 'the eye is never lying', this expression has a reflection when someone speaks, it can be seen with his eyes movement, whether he is 'honest' or 'lying'. But this part is very relative to be interpreted. 'Staring eyes' is a gesture that has a meaning such as; 'angry at someone', 'surprised at something' and the others.

\section{o. "Lifting an eyebrow"}

"Lifting one eyebrow" is a gesture that is most often used by all people and has many meaning "pointing at something object", "not believing in the other person" or "agree" toward a conversation. This gesture gives a different impression on an atmosphere because it has understanding'yes' or 'no' and it is necessary to clarify the meaning of the other person so that there is no misunderstanding. 


\section{p. "Lifting both eyebrows"}

This gesture has different atmosphere than others, because it expresses 'happy', feeling 'relief' cause of the result of a plan or an expression that shows a 'delicious' taste for the food served. And also expressed surprise at an object that might not have been seen before.

\section{q. "Meet Both Eye Brows"}

The meeting of the eyebrows is a form of gesture that has an effect on the facial expression that reflects a meaning of 'distress', confused ',' anger, and 'pain'. This Gesture sometimes can make us confuse toward speech opponents, therefore clarification is needed so that communication can occur.

r. "Wrinkle the Head".

"Wrinkle the Head" is the expression for "surprised" or "unreasonable". This gesture is used by everyone in expressing their emotions. "Wrinkle the Head" is very common in every conversation, especially in group discussions, feeling surprised at something strange, and sometimes expressing dislike of certain situations.

\section{s. "Body Style" Body Attitude.}

The attitude of this body can be indicated by a sitting and standing attitude. Seated attitude: "Sit politely", before the conversation begins sometimes everyone first "sit" to appreciate interlocutor, while the attitude of "standing up straight" can mean that someone wants to convey something explicitly ahead of course depending on the situation where we are and depends the person we are going to talk to is like an older person or when we are in front of the class preaching something. The next attitude is "chest forward", "shoulder pulled back" and lift your head up high, where the hand is hung on the side of the face. The meaning of this gesture expresses that the person concerned is "tired" or "less healthy".

\section{t. "Fake Smiles"}

Basically a smile is a symbol of happiness for everyone but this gesture is sometimes difficult to interpret in certain situations. Therefore we need an understanding toward this in order to we can understand the intent of the person who gave us a smile. In this case the smile can arise questioned which can make someone misunderstanding toward certainsituation. This expression shows a lie that can make people disappointed. Therefore it is very important to understand so we can take a more preventive.

\section{u. "Waving Hands"}

This gesture is very familiar to us as easterners, the meaning of this expression is a farewell to friends and guests who have visited a place. But in a western country waving is a sign or symbol calling someone to approach. 
v. "Patting the Head"

'Patting the head' is attitude which can be shown to someone who has 'failure' experiences and sometimes that someone wants to express something clear, of course depending on the situation where we are and depends on the person who we are talking to. The meaning of this gesture can also express that the person concerned "tired" or "forgets" something, therefore the reflex movement immediately of 'Patting the head'.

\section{w. 'Putall fingers together'}

Thisgesture is very rarely used in our place (Indonesia), "Put all Fingers together' means" feeding small children "or showing something a little ". But in other countries such as Italy, this gesture shows someone about 'what he wants' so that it can be accommodated but depending on the situation.

\section{x. "Cross Finger".}

This gesture can be said to be rarely found in Indonesia because "cross finger" is a symbol of love for Koreans. But for other communities such as in Vietnam, this indicates an impolite thing. But according to writer interviews with several young people around own environment, this gesture is often used to express affection to relatives, friends, even to their parents. But all of this is due to the influence of foreign cultures that surround the area.

\section{y. "Rubbing the Chin"}

"Rubbing the chin" for certain people is an ordinary movement and doesn't have any meaning. But in some other European countries such as Italy, this hand movements on the chin are very impolite because it can offend the person being talked because this gesture has the meaning of underestimating or degrading others.

z. "Calling by swinging the index finger"

"Calling by swinging your index finger" for certain people is a normal movement and doesn't have any meaning. But in some countries like Japan, this movement is to express 'death' while other countries may be 'pointing' somewhere.

\section{aa. "Finger Biting"}

"Finger Biting" is an ordinary movement and may not have meaning for most people, but this gesture in certain countries can show 'curious' about something, but it can also be interpreted as 'embarrassed' in presenting opinions in public.

bb. "Leaving Food at the Invitation to Eat"

For us, leaving food when invited by relatives is normal or can also mean 'want to eat'. But in other countries like Europe, this is very rude because it can offend the host because it can mean 'the food is not tasty'. Therefore, it is very important for us to understand that this context has not caused a misunderstanding. 


\section{E. Conclusion}

Some conclusions that we can take in the meaning of "gesture", among others:

1. Communication is not enough just to send a verbal message. Therefore nonverbal is needed in the context of situations and culture. Situation is a condition of someone who directly feels or experiences an event.

2. We cannot avoid the sign of language through hand movements and facial appearance.In the western part of the world certainly has difference cultural with the eastern world, where a perception will arise in every situation. Therefore the emergence of this perception is the existence of a diverse culture including expressions of language in "gestures". It is very important to understand in order to avoid cause of misunderstandings and can be understood by each other.

3. Nonverbal messages such as "gesture" are able to communicate emotions. This means that a number of expressions conveyed by users of these languages can be understood directly through nonverbal such as; 'eyes contact', 'smile', 'frown', 'hand shaking', 'wrinkle a head', etc.

4. This "gesture" language is closely related to the cultural context which is certainly supported by the participants.Language participants are very important in an interaction because they needed each other in establishing social relations, especially understanding is very important so that the message delivered goes well.

5. "Gesture" sign language has a different meaning from one another's culture. Every region or country has a different meaning in expressing language. This is caused of geographical, climate, customs, and the others. 
The Meaning Of Gesture ... [Najamuddin, S.Pd, M.Hum]

\section{Bibliography}

Alex Sobur. 2001. Analisis Teks Media. Remaja Rosdakarya: Jakarta

Eriyanto. 2001. Analisis Wacana : Pengantar Teks Analisis Media. LKIS : Yogyakarta

Kladen, N.P. 1999. Seni Memahami Sebagai Metode Humanitor: Jakarta

Levina. 1982. Beyond Languange Intercultural Communication For English As Second Languange. Printed In Printed Hall. Inc. Englewood Clifs.: USA

Maliki. 2006. Komunikasi Yang Efektif: Lembaga Administrasi Negara: Jakarta

Pradopo, Rahmat Joko. 1990. Pengkajian Puisi Analisis Strata Norma dan Analisis Struktural dan Semiotika. UGM Press: Yogyakarta

Sherzel, Joel. 1979. Exploration In Ethnograpy Of Speaking. Cambridge: Cambridge university Press

Sumaryono. 1993. Hemenetika Sebuah Metode Filsafat. Yogyakarta: Kanisius

Sutjiati, Beratha, Ni Luh. 2000. "Struktur dan Peran Semantis Verbal Ajaran Bahasa Bali" Dalam Bambang Kaswati Purwo (Penyunting). Kajian Serba Linguistik. Jakarta: BPK Gunung Mulia. 